\title{
Changes in the range of electric vehicles during operation
}

\author{
Arkadiusz Dobrzycki ${ }^{1}$, Michat Filipiak $^{1}$, Jarostaw Jajczyk $^{1{ }^{1 *}}$ \\ ${ }^{1}$ Poznan University of Technology, Faculty of Electrical Engineering, Piotrowo 3A, 60-965 Poznan, Poland
}

\begin{abstract}
This paper describes the trends in growth of the number of electrical vehicles in Europe. The most popular electric cars available on the market were presented, with the capacity of their batteries, energy consumption and range declared by the manufacturer. These data were confronted with the results of road tests. Assuming an average annual mileage, the number of charging cycles was estimated, and on this basis the decrease of battery capacity. The results of calculations were compared with the observations of electric vehicle users. The calculations showed a mileage, after which the user should consider battery packs replacing.
\end{abstract}

\section{Introduction}

Arguments which is in favour of the use of electric vehicles includes their ecological features, i.e. the minimum noise emission and the lack of emission of pollution into the air while in motion. The lower costs of use of such vehicles are also important. These features guarantee that they will constitute some of the leading means of transport in the future. Undoubtedly, the effect of such a situation will be an increase in the demand for electricity. Therefore, it is necessary to find solutions which will contribute to achieve as low energy losses as possible [1].

The use of electricity sources of good quality allows for the safe and failure-free use of the vehicles [2, 3]. At the same time small energy losses [4] during the charging process have a positive impact on their cost efficiency, which, in the long run, also affects the natural environment. The energy losses during the battery pack charge cause the generation of large amounts of heat, which reduces the battery life. This also translates into the smaller range and the frequent recharging of the batteries, which takes place, on many occasions, during the afternoon hours (instead of the more favourable night tariffs) [5-8]. Such a situation additionally causes more difficulties in the prediction of national power system loads.

\section{Electric vehicle market}

An increase in the sales volume of both electric and hybrid vehicles has been noticeable for several years. In Europe, the electric vehicles are much more popular. For instance, in Germany, the number of sold electric vehicles 2018 amounted to $1 \%$ of all new vehicles in general, i.e. over 36000 units [9]. Such sales results allow for the conclusion that the electric vehicle sales increase is unavoidable also in our country.
The commercially available electric vehicles are characterized by different ranges (declared by manufacturers) per single charge. Just as is the case with the combustion vehicles, the range depends on the weight of the vehicle, air resistance, rolling resistance and the external temperature. For forecasting range of the car it is important modelling of a similar way of using different vehicles. This allows making comparisons between results of analyses. An exemplary list of selected available vehicles, including capacities of their batteries, the range and energy intensity (energy needed to drive a $1 \mathrm{~km}$ ) was presented in figure 1.

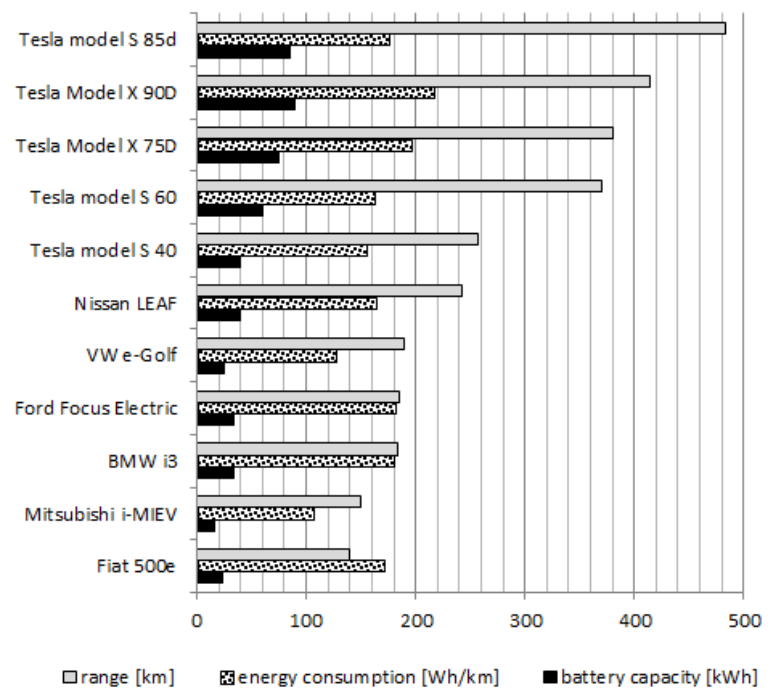

Fig.1 Battery capacity, declared range, energy demand (per $1 \mathrm{~km}$ ) for different electric vehicles [10]

The data collected by users of electric vehicle shows that the coverage of one kilometer requires from 200 to $250 \mathrm{Wh}$. Only in few cases, in the case of the energysaving driving style, it was possible to decrease the energy consumption to $158 \mathrm{Wh}$. 
Road tests [11] conducted on Zilent Courant, a vehicle equipped with 10 (lead-acid) batteries with a capacity of $110 \mathrm{Ah}$ and rated voltage of $12 \mathrm{~V}$, for which measurements were performed in very congested traffic, until driving outside the urban areas, the consumption reached the levels ranging between $155 \mathrm{Wh} / \mathrm{km}$ and $223 \mathrm{Wh} / \mathrm{km}$

For the most popular electric vehicle (Nissan Leaf), whose latest version from the year 2018 is provided with a $40 \mathrm{kWh}$ battery, and declared by the manufacturer range $(378 \mathrm{~km})$ was achieved, it gives the result at the level of $105.8 \mathrm{Wh} / \mathrm{km}$. The real range of this vehicle according to EPA (Environmental Protection Agency) gives the result of $243 \mathrm{~km}$, i.e. $164.6 \mathrm{Wh} / \mathrm{km}$.

\section{Electrical vehicles energy demand}

The range depends on the battery capacity, and the capacity gets reduced during time (in general with every charge cycle) when the vehicle is used. The dynamics of this reduction is influenced by the achieved level of cell voltage after the charging process. If the said level is exceeded, the battery capacity is reduced significantly.

An assumption was made that the vehicle covers $25000 \mathrm{~km}$ per year. This means that it covers $100 \mathrm{~km}$ a day only during the working days. In the case of Tesla model S - this means one vehicle charge per 2 days. For other vehicles, because of an uncertain situation on the road and the possible battery load, e.g. air-conditioning, heating or radio, it must be assumed that the battery packs should be charged on a daily basis (Fig. 1). According to the assumptions, 250 days of travelling results in 2000 battery charge and discharge cycles within 8 years (i.e. duration of the warranty).

The available information [12] regarding the total mileage of Nissana Leaf with the $40 \mathrm{kWh}$ battery, allow for the conclusion that the estimated total mileage of the electric vehicle is indeed achievable, but a decrease in the battery capacity will already be felt (Fig. 2).

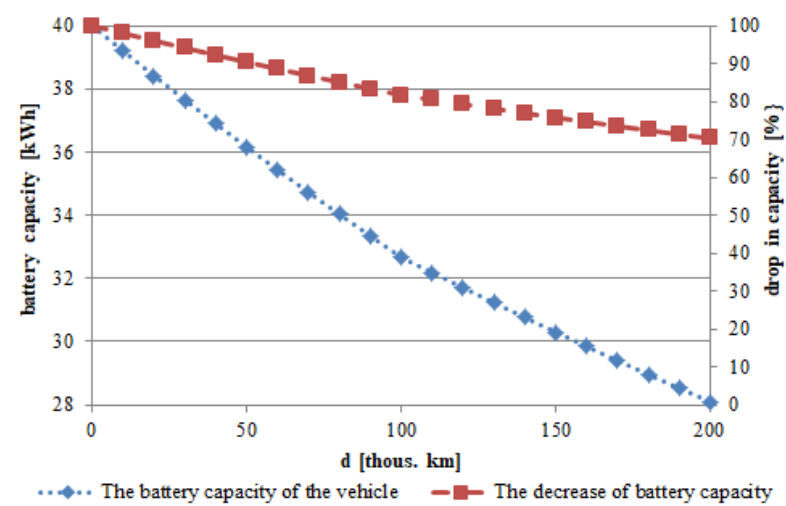

Fig. 2 Battery capacity changes in mileage for Nissan Leaf [12].

Figure 2 presents the capacity and its reduction vs. mileage. The $2 \%$ reduction in capacity was assumed for every $10000 \mathrm{~km}$ while the mileage were low than $100000 \mathrm{~km}$ and $1.5 \%$ capacity reduction was assumed for mileages above $100000 \mathrm{~km}[13,14]$.

\section{Conclusions}

The comfort of use of electric vehicles depends, to a great extent, on the availability of charging points, the mass of vehicles and the battery capacity, which affects the vehicle range. The battery life guaranteed by manufacturers is about 2000 charge cycles, and may be extended, if the appropriate charging regimes are maintained (especially, if the acceptable voltage per cell is not exceeded).

This paper has provided an estimation of the total range of selected vehicles supplied with electricity from battery packs. Analysis allows for the conclusion that about $10000-15000 \mathrm{~km}$ of mileage may be obtained from each installed $\mathrm{kWh}$ in the period of use of the vehicle (with the assumption of 2000 charge cycles). After this period, the use of the vehicle becomes troublesome because of the reduction in range (up to about $70 \%$ ). Further research work on modern electrochemical energy storages will limit the effect of battery capacity loss during their use.

\section{References}

[1] J. Jajczyk, A. Dobrzycki, M. Filipiak, D. Kurz, E3S Web Conf., 19, 01027 (2017), doi: $10.1051 / \mathrm{e} 3$ sconf $/ 20171901027$

[2] A. Dobrzycki, S. Mikulski, W. Opydo, Appl. Sci., 9, 1523 (2019)

[3] K. Bednarek, A. Bugała, D. Typańska, L. Kasprzyk, EKO-DOK 2018, E3S Web of Conferences, 44, 00010, 1-8 (2018)

[4] J. Jajczyk, A. Dobrzycki, M. Filipiak, ITM Web Conf., 19, 01034 (2018)

[5] A. Dobrzycki, M. Filipiak, J. Jajczyk, Poznan University of Technology Academic Journals. Electrical Engineering, 98, 159-169 (2019)

[6] A. Dobrzycki, M. Filipiak, J. Jajczyk, Poznan University of Technology Academic Journals. Electrical Engineering 95, $267-276$ (2018)

[7] J. Jajczyk, W. Lorkiewicz, ITM Web Conf., 19, $01036(2018)$

[8] D. Burzyński, D. Głuchy, M. Godek, ITM Web of Conferences 19, 01025 (2018)

[9] https://www.kba.de/DE/Presse/Pressemitteilungen/2 019/Fahrzeugzulassungen/pm01 $2019 \mathrm{n} 12 \_18 \_\mathrm{p}$ m_komplett.html?nn=646300 (08.04.2019)

[10] http://samochodyelektryczne.org (05.05.2019)

[11]W. Moćko, M. Ornowski, M. Szymańska, Zeszyty Problemowe-Maszyny Elektryczne, (2), 99. (2013)

[12] Nissan Leaf: 309 tysięcy kilometrów przebiegu, zostało 52 procent pojemności baterii http://elektrowoz.pl/auta/nissan-leaf-309-tysiecykilometrow-przebiegu-zostalo-52-procentpojemnosci-baterii (09.04.2019)

[13] Staff Car Report: At 70,000 Miles, 2011 Nissan LEAF Still Going Strong, Gets New Brake Pads https://transportevolved.com/2015/ 02/26/staff-car-report-at-70000-miles-2011-nissanleaf-still-going-strong-gets-new-brake-pads/ (10.04.2019)

[14] Staff Car Report: Nissan LEAF Loses its First Capacity After 3 Years, 52.8k Miles https://transportevolved.com/2014/04/22/staff-carreport-nissan-leaf-loses-first-capacity-3-years-528k-miles/ (10.05.2019) 